\title{
3. Tracking Wurnan: Transformations in the trade and exchange of resources in the northern Kimberley
}

\author{
Anthony Redmond
}

Trade: buy and sell, engage in...(in commodity, with person); have a transaction (with person for thing); carry merchandise (to place) [ME, F. MLG trade track, f. OS trada, f. tredan TREAD].

\section{- Concise Oxford Dictionary}

The recent intensification of the demands from a range of government agencies that Indigenous Australian landholders shift their focus from a previously valorized cultural identity-based attachment to land to an economic-development approach to those lands has drawn upon the long-prevailing perception of a sharp division between usufruct (a rights-based model) and landed cultural identities (an underlying title-based model) in traditional Aboriginal Australia. In this overly dichotomised schema, economic use rights occupy the unmarked position, reflecting the naturalisation of market-derived notions of the alienability of property while the marked position has been occupied by an exoticised notion of Indigenous people spiritually bound to country. This tendency to separate the cultural from the economic requires an exploration of some of the assumptions underpinning the supposed incommensurability of a modern economy and Aboriginal exchange networks.

In contrast with that dichotomisation between land rights/economy and land title/culture, this chapter explores transformations in the traditional wurnan trade network that overarches a number of socio-cultural regions in the Kimberley and beyond, operating at both small-scale interpersonal and largerscale inter-group levels, channelling ritual and simple economic objects of desire through predetermined but flexible trading routes (Redmond 2001).

The conceptual and political polarities between economy and culture referred to above have manifested in slightly different forms over time, so that sometimes they have been framed as a distinction between an enduring mythic consciousness with its timeless traditions attributed to indigenes and an agent-driven history with a peculiar capacity for innovation attributed to the colonial powers - in short, between modernity's focus on time as opposed to an Aboriginal focus on place (Rumsey 1994). ${ }^{1}$

1 Some might also recall here the debates sparked by Tony Swain's A Place for Strangers (1993). 
The same conceptual polarity has also been articulated in the anthropological distinction drawn between flexible economic bands, with their range of foraging grounds, vis-a-vis totemic clans, with their immoveable estate-based sacra and descent-based identities. This last distinction was, of course, fully elaborated by Les Hiatt in his 1962 critique of Radcliffe-Brown's long-prevailing model of the horde (1930-31), which had conflated the heterogeneous economic group possessing use rights in land with the more stable descent groups holding title to lands by dint of a sacralised ancestral identity.

Hiatt's necessary clarification of that issue subsequently spawned a tendency to over-sacralise Indigenous property rights so that cultural and economic property rights have often been construed as distinct. This division is reflected most clearly in the Aboriginal Land Rights (Northern Territory) Act 1976 (Cwlth) (NT $A L R A$ ), which defined the traditional owners for any tract of country with a double aspect: as someone with 'primary spiritual responsibility' for Dreaming sites (defining such owners by means of genealogical legitimation), and as those who use that tract of country in the sense of hunting and foraging.

This splitting off of an Aboriginal high culture from the economy has been made ever more explicit in native title case law, in which the holistic beneficiary possession originally inscribed in the Native Title Act 1993 (Cwlth) (NTA) has been reduced to a fragile and fragmented 'bundle of rights' resulting in a situation in which the right to trade in resources taken from a claim area has yet to be recognised by the courts. ${ }^{2}$ Opponents of such a right have generally mounted an argument that ritual objects rather than utilitarian ones were the main items of exchange in Aboriginal Australia, despite the abundant evidence that both these kinds of goods and services were exchanged or 'sold'.

The polarisation of ceremonial exchange vis-a-vis highly objectivised barter or pure trade has been a central analytical tool of social anthropology at

2 Northern Territory of Australia v Alyawarr, Kaytetye, Warumungu, Wakaya Native Title Claim Group [2005] FCAFC 135 (29 July 2005). The claim group comprises seven landholding estate groups of traditional country south-east of Tennant Creek. The court held that in relation to the pastoral lease land, native title rights were not exclusive, but did include a range of rights; however, the right to trade resources is not included. A right to trade the resources of the land may be regarded as a right in relation to land; however, in this case, there was insufficient evidence to support the finding of a native title right to trade in the resources of the claim area: [152]-[157]; Yarmirr v Northern Territory of Australia (1998) 82 FCR 533; Yanner v Eaton [1999] HCA 53; (1999) 201 CLR 351 considered. 156: 'The Northern Territory argued that the right to trade in the resources of the land necessarily implies a native title right to exclusive possession thereof. It was submitted that his Honour's reference to Yanner $v$ Eaton [1999] HCA 53; (1999) 201 CLR 351 and the absence of any right to own flora and fauna implied a view that the evidence was consistent with a native title right to take flora and fauna but not to own it. In any event, the evidence was said not to support any right to "trade" in the resources of the land as that term is generally understood...The Northern Territory argued that that evidence made no reference at all to any commercial or profit motives or any level of organised business operation.' 157: 'In his reasons for judgment the learned trial judge found that the use or exercise of the right to use and enjoy the resources of the claim area was well supported. Evidence had also been given by the applicants that they had asserted the right to use the natural resources of the claim area including water, trees, bush medicines, soakages, sacred sites and other things including ochre from various places in the claim area.' 
least since Malinowski's ethnography of the Kula trading ring (1922), which established a functionalist template for explicating the production of social cohesion and political alliance in the acephalous hunter-gather and/or smallscale horticultural societies of the British colonial possessions in Africa and Oceania.

Malinowski described various types of exchanges ranging from the 'free gifts' flowing between spouses and between fathers and their children to the various types of 'equivalent' and 'non-equivalent' exchanges that he saw as being spread across a continuous field, with non-relational barter or trade at the far end of his gift/exchange spectrum (Malinowski 1922:177-91) - a position that Sahlins later termed 'negative reciprocity' (1972).

Mauss's seminal, comparative monograph, The Gift (1924), drew extensively upon Malinowski's ethnography and drafted a template for modern sociology to draw distinctions between the personalising, exchange-focused gift economies of small-scale societies and the depersonalising independent transactor market economies of modernity.

The cultural capacity for reciprocity between persons and small groups in gift economies to 'annul time' was equated with an alluring capacity to annul political power (Gell 1992:24). Annette Weiner's critique of 'axiomatic reciprocity' in studies of Melanesian societies (1992) argued that 'the anthropological confidence' in reciprocity as the motivation for social exchanges in non-state societies - far from being an appreciation of marked cultural and economic difference-derived from the central place accorded to a norm of reciprocity elaborated in a political philosophy that 'has its roots in the market beliefs of Locke, Stewart and Adam Smith. These in turn arose from ideas about authority and the sacred in the Middle Ages where norms of reciprocity were used to sanctify dominant political hierarchies, involving gifts of patronage and charity' (Weiner 1992:28). ${ }^{3}$

This author suggested that if reciprocity is presented as 'natural' to man's economic and religious life, the give and take of exchanges between men and between men and gods allowed hierarchical relationships to be represented as mutually beneficial to all (Weiner 1992). Weiner went on to show how Henry Maine's distinction between 'moveable' and 'immovable' property posited the category of 'immovable' (that is, inalienable) property as the 'greatest impediment to the free circulation of objects' - the ultimate goal of an emergent commodity economy. The cosmological authentication of immovable property produced in origin myths and fictive or real genealogies gave rise

3 See Norman Freeman's A Short History of the Norman Conquest (1880) for an exploration of the notion of reciprocity as the essence of feudal relations. 
to high-status, 'transcendent' patrilineal possessions, such as inherited landed estates imbued with a quality of 'timelessness' derived from being repositories of gods and genealogies.

During her 1935-37 Kimberley fieldwork, Phyllis Kaberry quickly recognised the similarities between Malinowski's descriptions of the Kula and the regional institution of 'Wirnan', noting that cosmological beliefs about Galaroo, the Rainbow Serpent, permeated and authenticated this exchange network.

A man may sicken because he has not played his part in a particular kind of exchange resembling somewhat the Kula of the Trobriands. His exchange partner compels him to dream of a pearl-shell, one of the articles of exchange, and said to have been given to a man by the rainbow serpent. (Kaberry 1936: 284)

Kaberry produced a sketch map (Map 3.1) that showed that the routes along which different classes of items were traded in different directions from west to east were 'shells...mandi (stones), and sacred objects'. From east to west run 'dilly bags; fighting sticks; bamboo; wax; nagas; milinyin (bamboo shafts)'.

At the same time, 'reciprocity' was identified as a central organising feature of Arnhem Land ('Murngin') sociality in Warner's monograph A Black Civilization (1958, original 1937). Drawing on a functionalist model from Malinowski (1922), Warner described the 'ritual and economic reciprocity' that formed the 'fundamental basis of this ceremonial exchange which produces a stability and balance in the social relations of the groups and individuals. It organizes the structure of the economic group by the exchange of ceremonial objects' (1958:96). This was seen to mirror the reciprocity in marriage exchanges, together forming the ultimate basis of the local social contract. Donald Thomson's (1949) monograph on this subject, however, eschewed strong distinctions between ritual and economic exchanges, noting that for north-east Arnhem Landers, the ceremonial exchange cycle 'is not in any sense barter although circulation of goods on a large scale results' (1949:77). Thomson's view was ultimately consistent with that of Malinowski, who had noted that, while they appeared at opposite ends of a spectrum, in the Kula 'it is impossible to draw any fixed line between trade, on the one hand, and exchange of gifts on the other' (1922:176). 


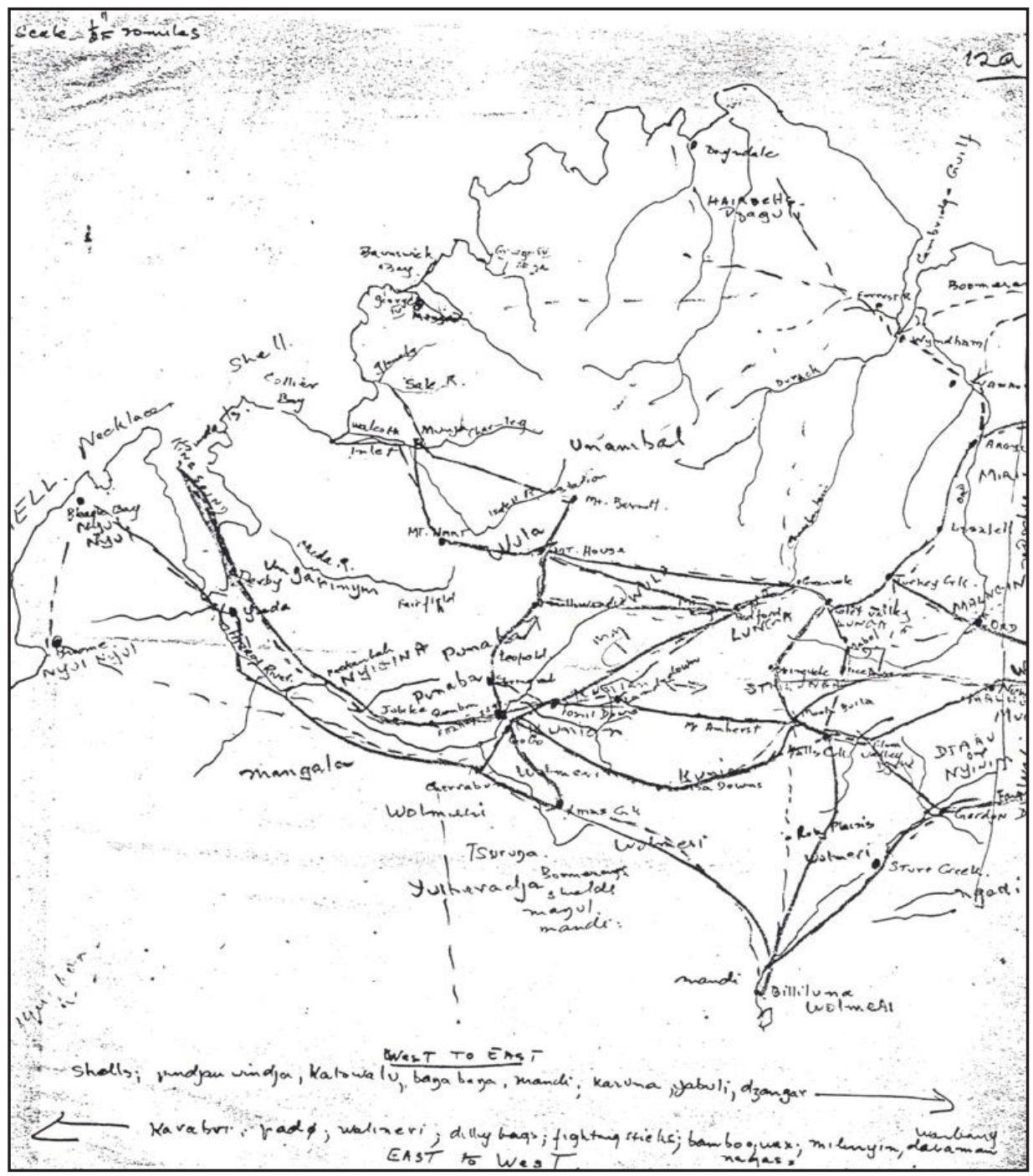

Map 3.1 Sketch map of trade routes in the Kimberley region

Source: Kaberry (1936). 


\section{Kimberley Ceremonial Exchanges and Trade}

Traditional Kimberley Aboriginal ritual and economic life were clearly not experienced as dichotomous realms of social life. The transactions that occur between groups and individuals through the wurnan channels have always involved pragmatic, ephemeral economic objects such as meat and hunting implements as well as ritual sacred/secret objects. Frederick McCarthy noted that

the making of gifts - foods, ornaments and weapons - is really part of the kinship system, forms a necessary adjunct to betrothal, marriage and initiation, and especially to the settling of grievances and quarrels; indeed it occurs at all large gatherings of natives...recent researches in north-eastern South Australia, north Western Australia, the Daly River district and elsewhere, have revealed that the economic customs and institutions dovetail into the kinship, ceremonial and legal aspects of social life. (McCarthy 1939:12)

McCarthy produced a map showing the north Kimberley trade routes and listing the objects exchanged through Ngarinyin country as 'stone axes, red ochre, stone spear points, bamboo spears' (McCarthy 1939:436). McCarthy noted that a single exchange object may have both pragmatic and ritual qualities compressed into it such as quartz spear-tips, which were used for the hunting of kangaroo as well as for revenge killings involving the dangerously magical properties of quartz. Another example of the compression of ritual/economic properties into an object is in gifts of chewing tobacco, which might contain ritual qualities from having been 'sung' by someone seeking to make the recipient a sexual partner. It is clear that other elements of the economics of everyday life (such as the increase ritual for the supply of available foods) are intimately bound up with ritual beliefs.

Tindale later recorded that objects as diverse as songs, ochres, shells, speartips, axes, second-hand clothes and scraps of tin and steel have made their way through the wurnan routes over the years (Tindale 1953:1015-17, 1033). As one senior Kimberley man told me: 'Man share 'em out, give me away everything wurnan, like selling clothes, present, all the spear, bush sugarbag, honey, that's what they do.'

Another noted:

Sometimes, if I need ochre for my paintings that I sell or else for a ceremony, I can make a private wurnan. I get in touch with my gumbali [namesake] in Kununurra and he will talk to his mob to make sure that it's OK. Then we can do a private trade without going through all the 
partners in between. Then when I see him next I can kill a kangaroo for him. Later on he might need something from me and he will let me know.

Another clear example of this ceremonial exchange for an only slightly delayed quotidian gift occurs in the yearly initiation ceremonies where clothes, cash and other presents are given to performers at the conclusion of the ceremonial cycle. Senior Ngarinyin man Paddy Neowarra told me how,

after we go to other communities for ceremonies, we will come back later to receive presents from them during a 'smoke', after all the business is finished. Everybody can relax then. People give us clothes and food and blankets for bringing our ceremony to them. Maybe to Looma or Fitzroy Crossing or Kununurra. Ceremony and everyday things are mixed up together.

This is how we trade one thing or another right across the Kimberley and down into the desert. All sorts of things, not just secret thing, but meat and sugar-bag, clothes and motorcars and money too. Or I might need a special type of wood for something I'm making or bamboo. All these sorts of things I can get through the wurnan.

This confluence between ritual and economic exchanges is particularly pronounced in gifts that are due to a man's in-laws. Peter Lucich, conducting fieldwork in Mowanjum and Kalumburu in 1963, found for instance that

the system for giving gifts to a waia (father-in-law) was named embadi... made up of durable goods such as mirrors, tomahawks and clothes. Previously, they had included spears, spinifex wax, pearlshells and hair-belts. If a man shared food in the settlement he was expected to give portions to his wife's parents, his own parents, and his immediate neighbours, in that order. (Lucich 1967:196)

Akerman subsequently demonstrated the efflorescence of this trade during his fieldwork in the early 1980s. ${ }^{4}$ Akerman's study of the wurnan showed that cash and food were amongst the objects that were traded and that by the mid1970s the trade routes had been re-routed through the pastoral stations and missions where the majority of people lived (Akerman 1980).

Map 3.3 is a conflation of a number of different ways of looking at Ngarinyin country. The base map shows the moiety blocs, mamalarrba and mornarrba, overlaid upon a clan map in which the clan epicentre is represented by the

4 Andrew Strathern described this impact of prestigious new goods from the colonial commodity economy accelerating the existing cycles of trade and exchange in local Indigenous gift exchange economy as 'efflorescence' (Gregory 1982:115, 166). 
small circles with numbers in the middle. Over the moiety shapes, I have drawn in the wurnan segments that Rumsey (1996) showed as links between many of the clans in the region. This produced the jagged series of lines, with directional arrows showing which clans made wurnan gifts in a major west to east branch of the exchange routes. Naturally, this jagged series of straight lines forms vectors only and does not represent the actual course over which wurnan would have been carried, which would have followed valleys and river courses. Thus, the tracks of the journeys would have responded much more closely to the contours of the country, also taking into account the position in which the wurnan gatekeeper would have been living at the time, and the locations within the clan countries of recognised Barurru (law grounds) for such exchanges, such as Monggowa, Nyaliga, Bijili, and so on. Nevertheless, even the straight lines linking clan epicentres tend towards a distinct patterning.

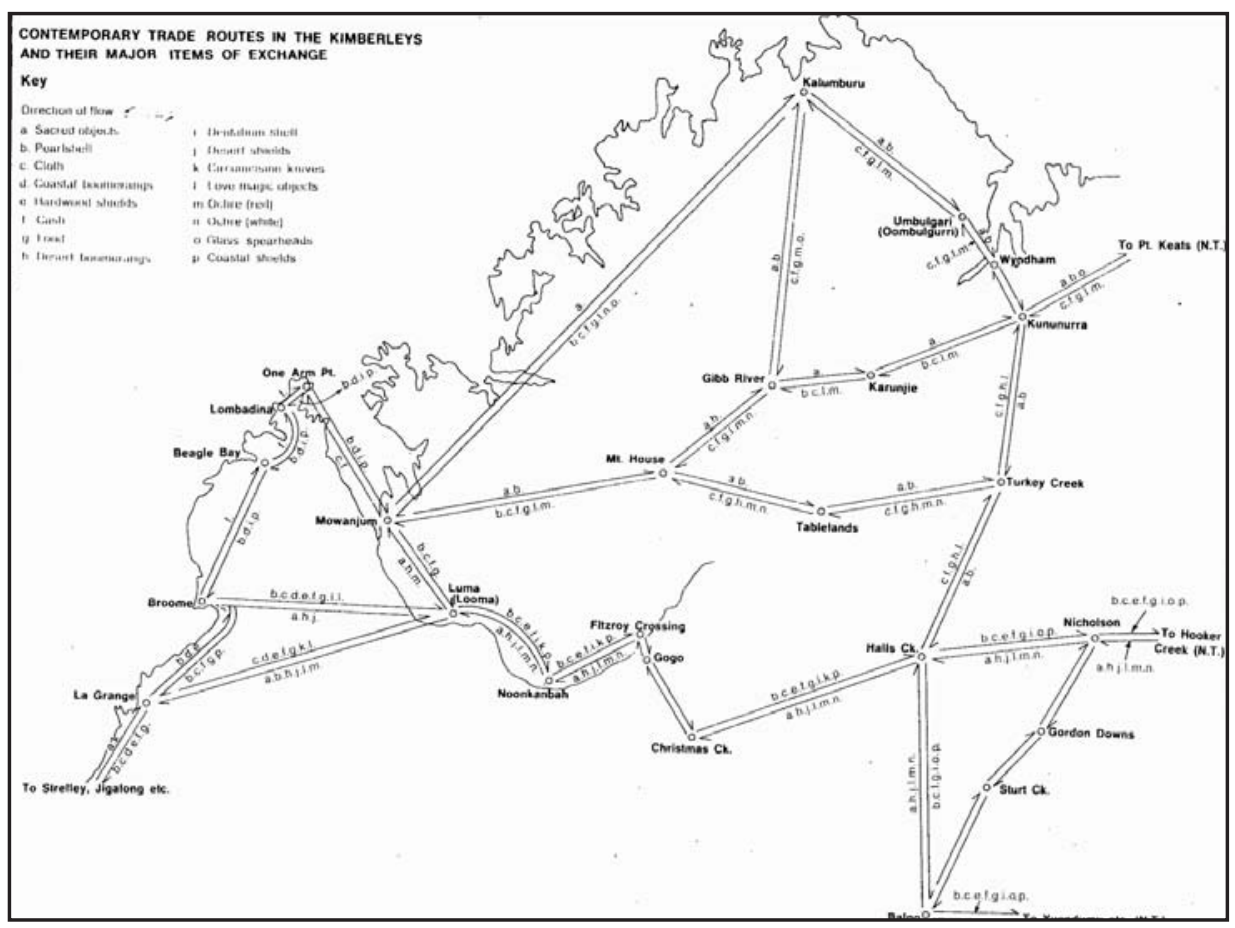

\section{Map 3.2 Contemporary Trade Routes in the Kimberleys and their Major Items of Exchange}

Source: Akerman (1980).

In the second stage of the process, I have then coloured the line segments to show what type of kin relationships exist between each of the particular clans that are linked by wurnan exchanges. The colour key on the map shows the relationship pertaining between the clans as wurnan partners, rather than an egocentric 
view of a person from one clan of all the other linked clans. Thus, at a clan level, each clan is assumed to be calling the other either the one relationship name or the two names that are available to the members of the adjacent generations of each clan. Thus, the green lines represent both a mother and a wife link for the members of the trading partners' clans, the orange lines both a mother-in-law and a mother's mother link, and the blue lines all the patrilineal links. The thin pink line, representing another branch of the wurnan running in the opposite direction (east to west), links clan countries for which I have not marked the nature of the kin relationships pertaining between them.

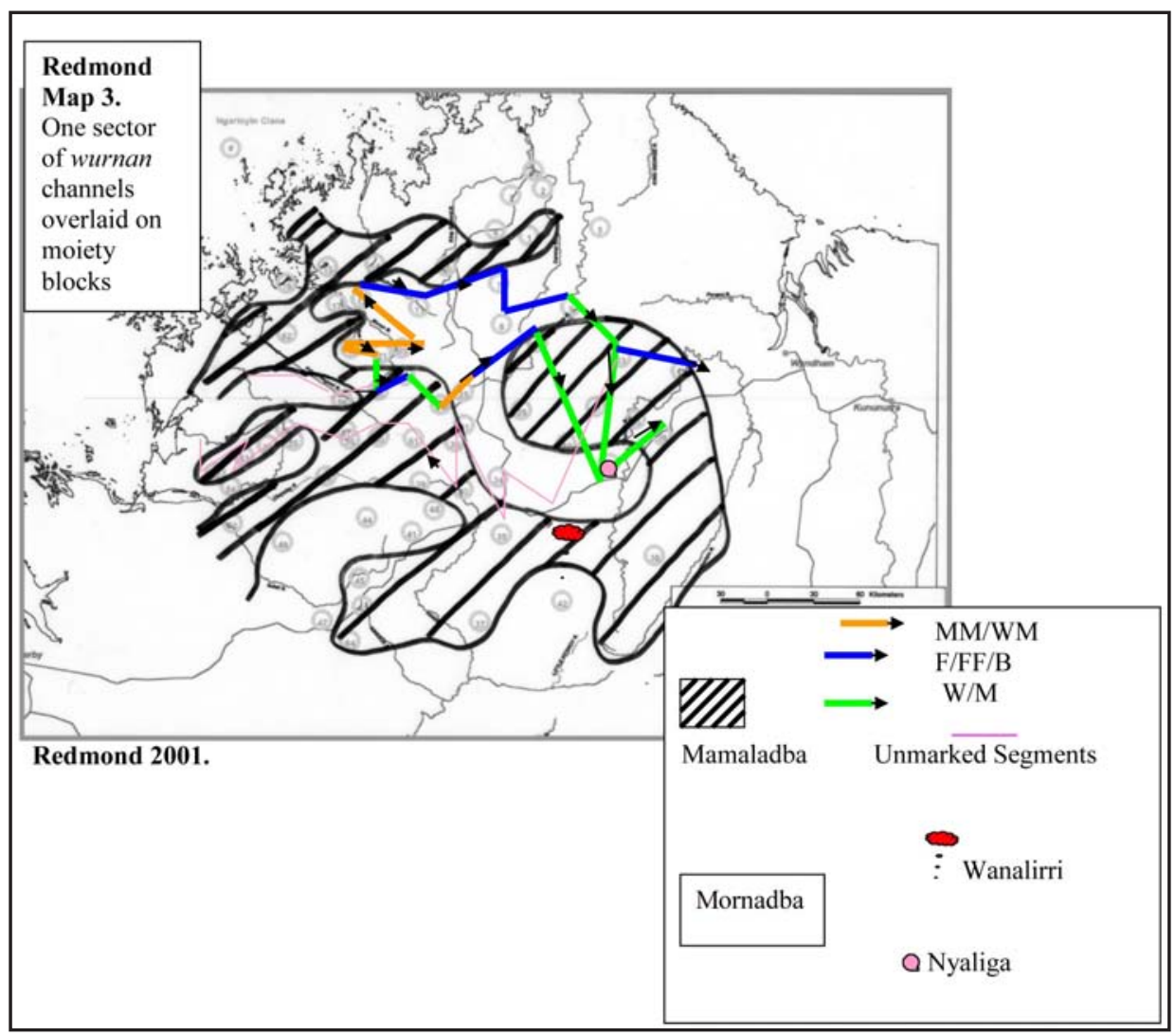

\section{Map 3.3 Wurnan channels overlaid on moiety blocks}

Source: Redmond (2001).

It will be observed that the coloured lines linking clans - the wurnan segmentsfollow rather closely the contours of the moiety shapes. It will also be evident that each time there is a linking green line (the $\mathrm{M}$ and $\mathrm{W}$ links), there is a crossing of the moiety boundary. On the other hand, the orange (MM/WM) segments and the blue $(\mathrm{F} / \mathrm{FF} / \mathrm{B})$ segments tend to mark out the boundary of the moiety shapes. I have included the location of the major wanjina gallery Wanalirri 
because it is from here that the distribution of wanjina across the entire region is said to have occurred and its position in a relatively narrow land bridge of mamalarrba country seems to be suggestive. I have also included the major wurnan site Nyaliga, located near Karunjie Station, to show its significant spatial positioning as a nyornarrba nodal point reaching into the heart of mamalarrba.

While maintaining their overall directionality, the wurnan channels can be rerouted to take account of the location of new communities. The law ground near the settlement where I lived played a crucial role in current exchange relations despite the settlement having existed in the general area only since the postwar period. As the holders of important ritual objects, a number of the senior residents formed a ritual partnership with another same-moiety man who acted as their 'manager' or 'player' in ceremonial activities. The status of being one who 'holds' objects, or country, was framed in terms of the nurturance attaching to the authority exercised in this ritual arena of men's sociality (see also Myers 1980a:119). This role places a responsibility on the participants to care for the country where the ritual objects are stored before they are passed along to their partners in neighbouring communities. As members of the Jun. gun moiety association of clans relating to each other as 'brothers, fathers and sons', the ritual relationships are underpinned by prior relationship between the clan countries that are jointly holding the objects of exchange (see also Blundell and Layton 1978). Significantly, although two of these senior men were said to be the holders of the objects, another man on whose clan country this ground lies was asserted to be the 'real boss'.

There is an integral connection between the relationship to countries that is forged through the initiation ceremonies and through ceremonial exchange networks. When initiates are sent to a far-flung community to 'go for law', ritual exchange objects are often sent back to the community to which the adolescents belong. While this exchange is delayed rather than direct, the exchange remains one way in which person and country are identified in the sense that a new social identity is created through initiation and the objects are provided as a kind of 'compensation' to the country and people who have 'lost a child'. This is certainly the case for one of these men's links, which emanated from his having taken over his older brother's role of initiator for a wide region of country. His services were thus in much demand and he was often engaged in negotiations with initiation bosses both outside and within the region.

In many of the settlements created after European settlement, such as the large encampment of Ngarinyin people that existed at Kimberley Downs until the 1980s, the camp itself was located adjacent to important wurnan trading locations. At Karunjie Station, the community was located at what was regarded by local people as a 'safe' distance from important wurnan storage places. The site for an emergent new community gained considerable local prestige from 
its proximity to a major wurnan intersection. It is at inter-group boundaries that the position of 'gatekeeper' (one who holds the 'seat' for a segment of the wurnan) is most important, since these individuals come to embody the social and cultural differences that are being both transcended and maintained through inter-group exchanges. Senior men with affinal ties to different cultural blocs acted as conduits with far-flung communities and commonly oriented their camps towards those places. The power of the wurnan to maintain social stability through 'ranking' individuals and communities in relation to each other is enforced by the sanction of expulsion from the wurnan, which effectively leaves a man 'outside the law' and thence socially and physically vulnerable. Someone who feels he has been 'left out of business' can also bring relationships between wurnan partners to crisis point by threatening to 'close the road' in his segment of the exchange route, thus bringing all exchanges to a halt since it is impermissible to deliberately bypass one sector of the exchange complex. Such closures can result in periods of stagnation in wurnan exchanges lasting several years, fuelled by the resentment of one man nursing a grievance of perceived neglect. Since these days the segments are actually linked by physical roads, the threat of a ceremonial 'road' closure has the possibility of inhibiting the movement of people between adjacent communities.

At least until the late 1990s, wurnan remained one of the strongest traditional social institutions operating across a wide area of the Kimberley in terms of intergroup communication and organised exchange. As such it carried enormous social prestige, which was enhanced by the secret/sacred nature of some of the exchanges that form its basis. ${ }^{5}$

Despite its capacity for flexibility, the wurnan system might become periodically ossified (though the process is perhaps already, in a local sense, 'ossified', the term wurnan being suggestively similar to wurnorr, a word meaning 'the bone of' - in this case, the social world). Stagnation results from a failure of participation by particular living people for one reason or another.

Many of the Ngarinyin myths about the founding of exchange relationships between groups and individuals in the Kimberley region have a strong focus upon vegetable foods, which became transformed into sacred objects and induced the necessity of organised sharing of resources. The feminine quality of the boards is underscored by the boards being known, in their most generic appellation, as mayangarri - a word glossed by Ngarinyin people as 'belonging to vegetable

5 One of the consequences of the prestige arising from the secret/sacred nature of the wurnan is that it has become a strongly identifying feature of Kimberley Aboriginal traditional political life vis-a-vis the colonial political structures that have been introduced over the past hundred years. Amongst these we must count the 'post-colonial' land councils and other forms of political organisation (such as the Aboriginal and Torres Strait Islander Commission) arising from the era in which self-determination was official Federal Government policy (1972-96). That policy has now been replaced with the much more conservative and market-oriented jargon of 'self-management'. 
foods'. They are regarded as 'life-giving' and 'full of Wunggurr' - evidenced by their lustrous fat-smeared surfaces, which keep them 'living'. Older people believed that 'garnmanggu [yam] and jarrgun [bush potato] all blang wurnan because everyone share that tucker'. Their association with angga-women's 'U'-shaped bark coolamons - as the holding body for the gathered vegetable foods highlights their capacity to symbolise the feminine power intrinsic to such foods. Nancy Munn came to a similar conclusion when she wrote that if we take the boards as being progeny of the women and as also containing the women's substance within them, then what the men take over is the objectified form of the "women-children" - that is, they take control of the immortal, objective aspect epitomized in the sacred boards' (1970:156).

One of the other major wurnan gifts was Gulangi black plum cakes, which were produced by washing, pounding and drying the fruit and then mixing this with 'sugarbag' (wild honey), the process and object being evocative of condensed female labour. This labour promotes the possibility of a convivial sociality, just as freshly baked bread and newly cooked damper from the coals now always elicit a gathering of young men and women around the fire. ${ }^{6}$ In wurnan exchanges, a baler shell filled with honey was commonly presented to a partner with ribald comments concerning its female symbolism.

In the story of how men came to possess these sacred boards, the stolen objects are said to have originally belonged to women. ${ }^{7}$ An old woman, Nyambuliji, had been blinded by gorid, a whirlwind, which allowed her husband, Wibalma, to take them from her and then to fashion his own. His wife's blindness conveniently allows Wibalma to continue to fashion his boards without women being able to view them-a practice that persists to this day. ${ }^{8}$

The moiety heroes, Wodoy and Jun.gun, subsequently steal the boards from Wibalma, escaping with the embodiments of his wife's sexuality and fertility. ${ }^{9}$ The moiety heroes banded together to steal the boards because Wibalma had tried to store the boards and keep them for himself, refusing the sociality of others. After stealing the boards, the moiety heroes, Wodoy and Jun.gun, instituted the marriage system of exchanges of women between moieties by fighting over the stupidity of Jun.gun in trying to cook honey and planning to marry his own daughter (see also Blundell and Layton 1978).

\footnotetext{
6 Love noted that 'the camps of young men, who have no wives, will share in the vegetable food, which it is specially the province of the women to provide, and the married men, too, will receive food from other women than their own wives' (1936:73).

7 This is a very common theme in regards to sacred objects (cf. Berndt 1952:16-17; Morphy 1991:86; Strehlow 1947:94; Taussig 1999:180).

8 In a Papunya story with similar thematics, the husband, rather than the wife, is blind (cited by Morton 1985:129).

9 Roheim noted of the ancestral Arrernte women who held sacred objects that 'an alknarintja woman means a woman who "turns her eyes away"' (1971:156).
} 
In the foundational wurnan story, the plum cake is stolen by a female emu who escapes from the sphere of exchange in which the different clan animals are instituting the law for sharing. She absconds with this plum cake tucked under her wing only to be speared to death, finally becoming embodied in the dark hole of the Milky Way, the spears still visible in her body, forever grazing on the ground beneath the gulangi tree, which forms the Southern Cross (see also Morton 1985:120).

The relationships most marked by avoidance for Ngarinyin people are those between people who are defined as rambarr - mother-in-law and son-in-law to each other (that is, those who are linked by the transmission of female resources). Wurnan partners live in anticipation of receiving objects that both increase their charisma and enhance human fertility. This is achieved through expressive acts of giving, the expansion of the self into widening circles of relatedness.

The concealing containers in which wurnan gifts are given-from the honeyfilled baler shell and the spear-tips wrapped in paperbark to the sweat-stained old shirt in which red ochre is passed on-all partake of a powerful female embodiment. The paperbark, wulun (wulun nyindi is an idiomatic reference to woman in Ngarinyin), wallets, nguwarra, are bound with red-ochre-stained string just as the bones of funerary packages are presented to the maternal relatives for cradling before second burial.

\section{Wurnan and Karunjie Station}

For many Kimberley Aborigines, much of the significance of Karunjie Station in the north-east Kimberley derives from the ways in which the Indigenous and settler cultures and economies have been inextricably interwoven throughout living memory. This station lease, originally taken by hard-bitten, repatriated World War I veterans and 'Afghan' (actually north Indian) cameleers, some of whom had also fought with the British Army in Afghanistan, was the location of one of the biggest exchange centres in the region, drawing in sometimes hundreds of participants to its wurnan ceremonies where bolts of red cloth from the Chinese stores in Wyndham port, as well as spear-tips, bamboo, shells and ochres, were traded. By the early 1920s it had also become a ration depot to induce some of those who were there for ceremony to stay for longer periods and to work at the station. Others were drawn into working on sandalwood finding and cutting, which the Afghan camel teams then carried overland to Wyndham port from where it was shipped to South-East Asia for joss-stick manufacture.

In my earlier paper with historian Fiona Skyring (Redmond and Skyring 2010), we analysed the effects of the emergent frontier economy of the interwar period 
in creating an efflorescence of wurnan trade, not dissimilar to that discerned by Kim Akerman in the late 1970s when wages, welfare cash, vehicles and a capacity for high mobility first became available to Aboriginal pastoral workers.

One of the consequences of the ritual prestige of the wurnan in the twenty-first century is that it has now become a strongly identifying symbol of continuing desires for an autonomous Aboriginal political life vis-a-vis the post-colonial political structures such as land councils and resource agencies introduced over the past 30 years. I perceive a strong desire amongst many Indigenous people to keep this distance and autonomy between wurnan relationships and the post-1980 corporatisation of Aboriginal political life. This means always staying a diffident step ahead of the creeping tide of acronyms and acrimonies of government agencies, which are now major political players in Kimberley economic life. The perceived dangers associated with wurnan's ritual objects help to deter the complete absorption of the Indigenous economy into the mainstream economy and continue to allow a sociopolitical space for Kimberley people to set their own 'gold standards', prices and exchange rates within a semi-compartmentalised intra-Indigenous domain.

The Indigenous desire for this form of political autonomy, however, ought not cover the tracks of the obvious - namely, that the level of autonomy that is demanded by the post-welfare state is likely to be possible only if the Indigenous right to trade in the resources of native title claim areas is recognised by the courts as a right flowing from the inextricably bound nature of economic and ritual exchanges inherent to the underlying Aboriginal title to those lands.

\section{References}

Akerman, K. 1980. Material culture and trade in the Kimberleys today. In Aborigines of the West: Their past and their present. Perth: University of Western Australia Press.

Berndt, R. M. 1951. Ceremonial exchange in western Arnhem Land. Southwestern Journal of Anthropology 7 (2): 156-76.

Berndt, R. M. 1952. Djanggawul. London: Routledge and Kegan Paul.

Blundell, V. and Layton, R. 1978. Marriage, myth and models of exchange in the west Kimberleys. Mankind 11: 231-45.

Freeman, A. 1880. A Short History of the Norman Conquest of England. Oxford: Clarendon Press.

Gell, A. 1992. The Anthropology of Time. Cambridge: Cambridge University Press. 
Gregory, C. 1982. Gifts and Commodities. London: Academic Press.

Hiatt, L. R. 1962. Local organization among the Australian Aborigines. Oceania 32 (4): 267-86.

Jebb, M. 2002. Blood, Sweat and Welfare: A history of white bosses and Aboriginal pastoral workers. Perth: University of Western Australia Press.

Kaberry, P. 1935-6, AIATSIS MS739/2 Item 14. Sketch Map of trade routes in the Kimberley region, Australian Institute of Aboriginal and Torres Strait Islander Studies, Canberra.

Love, J. R. B. 1936. Stone Age Bushmen of Today: Life and adventure among a tribe of savages in north-western Australia. London and Glasgow: Blackie \& Son.

Lucich, P. 1967. The development of Omaha kinship terminologies in three Australian Aboriginal tribes of the Kimberley division, Western Australia. MSc in Anthropology thesis, University of Western Australia, Perth.

McCarthy, F. D. 1939. Trade in Aboriginal Australia, and trade relationships with Torres Strait, New Guinea and Malaya. Oceania 9 (4) (1939): 405-38; 10 (1) (1939): 80-104; 10 (2) (1939): 171-95.

Malinowski, B. 1922. Argonauts of the Western Pacific. London: Routledge and Kegan Paul.

Mauss, M. 1954. The Gift. London: Routledge.

Morphy, H. 1991. Ancestral Connections: Art and an Aboriginal system of knowledge. Chicago: University of Chicago Press.

Morton, J. 1985. Sustaining desire: a structuralist interpretation of myth and male cult in Central Australia. 2 vols. Unpublished PhD thesis, Australian National University, Canberra.

Munn, N. 1970. The transformation of subjects into objects in Walbiri and Pitjanatjara myth. In Ronald M. Berndt (ed.), Australian Aboriginal Anthropology: Modern studies in the social anthropology of the Australian Aborigines. Perth: University of Western Australia Press.

Myers F. 1980a. The Cultural Basis of politics in Pintupi Life. Mankind 12 (3): 197-214

Peterson, N. 1997. Demand sharing: reciprocity and the pressure for generosity among foragers. In F. Merlan, J. Morton and A. Rumsey (eds), Scholar and Sceptic: Australian Aboriginal studies in honour of L. R. Hiatt. Canberra: Aboriginal Studies Press. 
Radcliffe-Brown, A. R. 1930-31. The social organisation of Australian tribes. Parts 1 \& 2. Oceania 1: 34-63, 199-246.

Redmond, A. 2001. Rulug Wayirri: moving kin and country in the northern Kimberley. Unpublished PhD thesis, University of Sydney, Sydney.

Redmond, A. and Skyring, F. 2010. Exchange and appropriation: the Wurnan economy and Aboriginal land and labour at Karunjie Station, north-western Australia. In I. Keen (ed.), Indigenous Participation in Australian Economies: Historical and anthropological perspectives. Canberra: ANU E Press.

Roheim, G. 1971 [1945]. Eternal Ones of the Dream. New York: International Universities Press.

Rumsey, A. 1994. The Dreaming, human agency and inscriptive practice. Oceania 65: 116-31.

Rumsey, A. 1996. Aspects of native title and social identity in the Kimberleys and beyond. Australian Aboriginal Studies 1996 (1): 2-10.

Sahlins, M. 1972. Stone-Age Economics. New York: Aldine.

Schutz, A. 1967. Collected Papers. Volumes 1 and 2. The Hague: Nijhoff.

Strehlow, T. G. 1947. Aranda Traditions. Melbourne: Melbourne University Press.

Swain, T. 1993. A Place for Strangers. Towards a history of Australian Aboriginal being. Cambridge: Cambridge University Press.

Taussig, M. 1999. A joyous thing with maggots at the centre. In Defacement: Public secrets and the labour of the negative. Stanford, Calif.: Stanford University Press.

Thomas, N. 1991. Entangled Objects: Exchange, material culture, and colonialism in the Pacific. Cambridge, Mass.: Harvard University Press.

Thomson, D. F. 1949. Economic Structure and the Ceremonial Exchange Cycle in Arnhem Land. Melbourne: Melbourne University Press.

Tindale, N. 1953. Anthropological field notes on the UCLA-UA Anthropological Expedition, NW Australia. Unpublished, South Australian Museum, Adelaide.

Warner, W. Lloyd 1958. A Black Civilization: A social study of an Australian tribe. New York: Harper \& Brothers.

Weiner, A. 1992. Inalienable Possessions: The paradox of keeping-while-giving. Berkeley: University of California Press. 